\title{
ARCHAEOLOGIES OF THE CONTEMPORARY WORLD
}

Rodney Harrison ${ }^{1}$ and Esther Breithoff ${ }^{2}$

Pre-print version; accepted for publication in Annual Review of Anthropology Vol. 46:- (Volume publication date November 2017)

DOI: 10.1146/annurev-anthro-102116-041401

\section{Keywords}

Archaeologies of the contemporary world; ethnoarchaeology; archaeological ethnography; modern material culture studies; multi-temporality; future worlds

\begin{abstract}
Archaeologists have long been interested in contemporary material culture, but only recently has a dedicated subfield of archaeology of the contemporary world begun to emerge. Whilst concerned mainly with the archaeology of the early to mid-twentieth and twenty-first centuries, in its explicit acknowledgement of the contemporary archaeological record as multi-temporal, it is not defined by a focus on a specific time period so much as a particular disposition towards time, material things, the archaeological process and its politics. This paper considers how the subfield might be characterised by its approaches to particular sources and its current and emerging thematic foci. A significant point of debate concerns the role of archaeology as a discipline through which to explore ongoing, contemporary socio-material practices - is archaeology purely concerned with the "abandoned" and the "ruined", or can it also provide a means by which to engage with and illuminate ongoing, contemporary and future socio-material practices?
\end{abstract}

\section{Headings}

Introduction

Sources and approaches: Ethnoarchaeology, archaeological ethnography, historical archaeology and archaeologies of the "contemporary past"

The "recent" and "contemporary" as chronological, spatial or ontological categories

The ethics and politics of archaeologies of the contemporary world

Concluding Remarks: On the potential for archaeologies of the contemporary world to reshape the future

\section{Literature Cited}

Related Resources

\footnotetext{
${ }^{1}$ UCL Institute of Archaeology, r.harrison@ucl.ac.uk

${ }^{2}$ UCL Institute of Archaeology, e.breithoff@ucl.ac.uk
} 


\title{
ARCHAEOLOGIES OF THE CONTEMPORARY WORLD
}

\begin{abstract}
Archaeologists have long been interested in contemporary material culture, but only recently has a dedicated subfield of archaeology of the contemporary world begun to emerge. Whilst concerned mainly with the archaeology of the early to mid-twentieth and twenty-first centuries, in its explicit acknowledgement of the contemporary archaeological record as multi-temporal, it is not defined by a focus on a specific time period so much as a certain disposition towards time, material things, the archaeological process and its politics. This paper considers how the subfield might be characterized by its approaches to particular sources and its current and emerging thematic foci. A significant point of debate concerns the role of archaeology as a discipline through which to explore ongoing, contemporary socio-material practices - is archaeology purely concerned with the "abandoned" and the "ruined", or can it also provide a means by which to engage with and illuminate ongoing, contemporary and future socio-material practices?
\end{abstract}

\section{KEYWORDS}

Archaeologies of the contemporary world; ethnoarchaeology; archaeological ethnography; modern material culture studies; multi-temporality; future worlds

\section{INTRODUCTION}

What has become known as the "archaeology of the contemporary world" (c.f. Graves-Brown et al. 2013a) or the "archaeology of the contemporary past" (c.f. Buchli and Lucas 2001a) has emerged over the past two decades as a dynamic and expanding subfield of archaeology. Whilst many proponents are clear that the subfield is not purely defined by a particular chronological focus (see Harrison et. al. 2014), it represents a loosely programmatic engagement with recent or contemporary global material cultures, with this recent or contemporary past generally understood 
as a period beginning sometime during the early to mid-twentieth century and extending to the emergent present, or "now" (c.f. Harrison 2011, Harrison \& Schofield 2010, Holtorf \& Piccini 2009). While the subfield overlaps partially with other established and emergent subfields, in particular archaeological ethnography (see review in Hamilakis 2011), ethnoarchaeology (see further discussion below), modern conflict archaeology (see reviews in Crossland 2011, Moshenska 2013), forensic archaeology (e.g. Powers \& Sibun 2013), archaeologies of contemporary internment and confinement (e.g. Myers \& Moshenska 2011) and disaster archaeology (Gould 2007), practitioners increasingly self-identify this subfield and publish across a range of new and established journals, in edited collections and monographs (e.g. Andreassen et al. 2010, GravesBrown et al. 2013a, Burström 2012, Burström et al. 2011, Finn 2001, González-Ruibal 2013, 2014, Harrison \& Schofield 2009, Holtorf \& Piccini 2009, Fortenberry \& Myers 2010, Fortenberry \& McAtackney 2012, May \& Penrose 2012, McAtackney et al. 2007, Olsen \& Pétursdóttir 2014, Orange 2015, Schofield 2009). Rather than take a strictly historical approach (e.g. see previous reviews in Fewster 2013, Harrison 2011, Harrison 2016, Harrison \& Schofield 2010, Harrison et al 2014, Hicks 2010), and in an attempt to avoid some of the problems of definition which have been noted elsewhere (Graves-Brown et al. 2013b, Piccini \& Holtorf 2009), here we review the subfield thematically, exploring it not so much as defined by a focus on a specific temporal period as reflecting a particular disposition towards time, the archaeological process and its politics. We suggest the subfield might be further defined by its approaches to particular source materials, here noting the ways in which it partially overlaps with but also distinguishes itself from adjacent subfields of historical archaeology, ethnoarchaeology and archaeological ethnography. One significant point of debate concerns the role of archaeology itself as a discipline through which to explore ongoing, contemporary socio-material practices - is archaeology purely concerned with the "abandoned" and the "ruined", or can it also provide a means by which to engage with and illuminate ongoing, contemporary socio-material practices? We also note the particular themes and topics which have characterized the field, exploring what may be considered to be distinctive about 
its subjects of research and its methodologies. In doing so we consider how the archaeology of the contemporary world challenges archaeological conventions of temporality, and relates to discussions of time in other areas of archaeology (e.g. discussions of archaeology and ontology, see Alberti 2016). Finally, we point to the potential for the subfield to address contemporary global concerns, from the failure of the modernist project to undocumented migration and climatic change. Whilst our review is limited mostly to English language sources, it is important to note that the subfield has also developed along parallel and divergent trajectories in Spain, Latin America, France and the Nordic countries, with each influencing the trajectories of the archaeology of the contemporary world in English speaking countries significantly as a result.

\section{SOURCES AND APPROACHES: ETHNOARCHAEOLOGY, ARCHAEOLOGICAL ETHNOGRAPHY, HISTORICAL ARCHAEOLOGY AND ARCHAEOLOGIES OF THE "CONTEMPORARY PAST"}

It has been noted elsewhere that the interpretation of the archaeological record through the study of contemporary material culture has been a feature of archaeological interpretation since its very beginnings (Buchli 2002, Hicks 2010). Yet it is now generally acknowledged that it was the strong interest in contemporary material cultures within the New Archaeology's search for middle range theory in the 1960s and 1970s - especially that which became popularly known as "ethnoarchaeology" - that led to the first formal publications on the archaeology of the contemporary world (but see some important earlier precedents in Redman 1973, especially Salwen 1973, Leone 1973). Rathje's article "Modern material culture studies” (Rathje 1979, see also 1978) and Gould and Schiffer's (1981) edited volume Modern material culture: The archaeology of us grew out of the research developed by Schiffer and Rathje at the University of Tucson, Arizona and separately by Gould at the University of Honolulu, Hawaii during the 1970s. Where most ethnoarchaeological research had tended to be undertaken with communities who employed traditional technologies in a contemporary setting (e.g. Binford 1967, 1978, Gould 1980), the student programs developed at Tucson and Hawaii, and by contributors to Modern material culture, 
distinguished themselves through their focus on the description and analysis of contemporary material cultures largely based in modern industrial and post-industrial societies. This initial North American efflorescence of research on the archaeology of modern material culture spawned important research programs, including Rathje's important Garbage Project (e.g. Rathje 1991, 2001, Rathje \& Murphy 1992), and work by Gould (e.g. 2007) and Schiffer (e.g. 1991, 2000), and indeed all three scholars established a central place for themselves within the development of North American archaeological theory and method. However, much ethnoarchaeology throughout the 1980s and early 1990s remained focused on traditional forms of technology, and on the use of ethnoarchaeological models for the explanation of cultural change in the past (see e.g. David \& Kramer 2001).

An interest in archaeological approaches to the contemporary world re-emerged amongst British "post-processual" archaeologists in the 1980s. Other reviews have pointed to the significance of Hodder's (1987) study of the social meaning of bow ties in a contemporary British pet food factory, as a case study for modeling the relationship between social practices, material culture, and meaning in human societies. Similarly, in Reconstructing Archaeology, Shanks and Tilley (1992) also explored contemporary material culture through a study of the design of Swedish and English beer cans. In their introduction to this case study, they criticized the authors of the chapters in Modern material culture for being too empiricist in their approach, suggesting that they "failed to realize the potential of the study of modern material culture as a critical intervention in contemporary society... with transformative intent” (Shanks \& Tilley 1992, p. 172). Fewster (2013) notes the ways in British post-processual ethnoarchaeologies in this period emphasized the role of informants in understanding the contemporary meaning of material cultures and how this prompted a move away from an understanding of ethnoarchaeology as purely concerned with the production of analogies for interpreting the (past) archaeological record, to an understanding of an informantled ethnoarchaeology as having a significant role in the interpretation of contemporary life (see 
González-Ruibal 2003 for an introduction to ethnoarchaeology in Spanish). Fewster's (2007) own work in the contemporary interpretation of archaeological sites in Central Spain is a significant example of this move, as is Moore's work in Kenya (1986) (see also for example more recent work by Flexner 2016, González-Ruibal, Hernando \& Politis 2010, Torrence \& Clarke 2016).

Fewster (2013) also shows how the archaeology of the contemporary world developed along a quite different trajectory during this period, initially distinguishing itself from the contemporary anthropological approaches to material culture which were emerging simultaneously in Britain in the work of Danny Miller (e.g. Miller 1987, 1994, 1998) and his students and colleagues, as well as from British and North American postprocessual ethnoarchaeology, in its focus on abandoned, and often ruined, objects and places, and its emphasis on a material-led, rather than informant-led, forms of archaeology. This emphasis on material-led archaeology was a significant feature of many if not most of the papers in two key edited volumes that became central to the establishment of the archaeology of the contemporary as a subfield in the English speaking world-Matter, materiality and modern culture, edited by Paul Graves-Brown (2000a), and Archaeologies of the contemporary past, edited by Victor Buchli and Gavin Lucas (2001a). Graves-Brown (2000b) suggested that the role of an archaeology of the recent past was to make the familiar "unfamiliar", to destabilize aspects of contemporary quotidian life which would otherwise be overlooked. It would do this through the application of archaeological methods, which most would think of as designed to approach a temporally and culturally distant subject, to "our" own material cultures (whoever, "we" might refer to here, see Graves-Brown et al 2013b). Buchli and Lucas (2001b, 9) also emphasized this aim, suggesting that "there is a sense in which turning our methods back on ourselves creates a strange, reversed situation-a case of making the familiar unfamiliar". This aim, to explore the distinctively "archaeological" contribution to the study of contemporary material cultures, meant that a significant proportion of the work stimulated by these two books tended to focus rather heavily on material forms of evidence, arguably to the detriment of oral and documentary records. 
Thus, and perhaps counterintuitively, the archaeology of the contemporary world as it developed over the first decade of the 2000s generally had much closer ties with prehistoric archaeology than with historical archaeology. As Gavin Lucas notes, this is perhaps because in its earliest incarnations it was seen to be connected closely with the more general project of developing middle-range theory (Lucas in González-Ruibal et al. 2014, p. 266). So, while many who work on "recent" and "contemporary" time periods today might also work on material that might be more conventionally understood as falling within the purview of historical archaeology, the connections between theoretical and conceptual developments within each of these two subfields have been relatively weak (this section after Harrison 2016, see also McAtackney \& Penrose 2016). Yet, besides sharing temporal boundaries, it seems that there are many broader themes that constitute areas of shared interest. For example, the interest of scholars working on the archaeology of the contemporary past in questions of inequality, power, and class (De León 2016, Gokee \& De León 2014, Kiddey \& Schofield 2011, Zimmerman 2013, Zimmerman \& Welch 2011, Zimmerman et al. 2010), resonates strongly with a long tradition of engagement with the sociopolitics of pasts in the present and attempts to trace the genealogies of modern global inequalities in historical archaeology (Hall 2000, Hall and Silliman 2006, Leone 2005, Leone \& Potter 1999, Matthews 2010, McGuire \& Paynter 1991, Mullins 1999, 2010, Singleton 1999, Tarlow 2007, Voss 2008). Similarly, the strong orientation within historical archaeology toward a critical engagement with colonialism and postcolonial theory (e.g. Silliman 2004, Lydon 2009, Leone 2009, Croucher \& Weiss 2011), can also be seen to intersect clearly with approaches that have characterized archaeologies of the contemporary (e.g. González-Ruibal 2014). Yet it remains quite clear that the archaeology of the contemporary world has not really intersected with historical archaeology as it is practiced in Anglo-American contexts. It is possible to argue that this is at least partially a function of the different approaches to and emphases on particular kinds of sources that have been developed within each subfield. While both have been explicitly concerned with the question of sources, 
historical archaeology has developed a strong approach to the integration of multiple lines of evidence, arguably with an emphasis on textual and visual sources in addition to material ones. The integration of multiple lines of evidence as part of an interpretive historical archaeology has received much critical focus and discussion (e.g. Beaudry 1988, 1995, Schuyler 1978, Wilkie 2006). As noted above, the archaeology of the contemporary world, on the other hand (at least in its early incarnation during the first part of the new millennium) has tended to prioritize material sources explicitly over textual or remembered ones. One could easily see this as a legacy of the experimental nature of the subfield and the ways in which, at least in so far as it was developing in the early 2000s, it sought to justify the value of an explicitly archaeological approach to the study of contemporary life, given the abundance of other source materials available that cover the same temporal ground (see further discussion on its engagement with archaeological process below). But it is also, perhaps, one reason the subfield has found itself relatively isolated from historical archaeology, particularly in North America, where there has been a long and strong tradition of documentary archaeology, at least some of which has extended into twentieth-century contexts (e.g. Cabak et al. 1999, Wilkie 2010).

The controversial "Van" project (Bailey et al. 2009, see further discussion in Harrison \& Schofield 2010, p. 157-163), is a good case in point. This project involved the "excavation" of a 1991 model Ford Transit van by a group of archaeologists in Bristol. Much of the online discussion around the project focused on whether it should or should not be perceived to be archaeology, and whether such an exercise could be seen as worthwhile (Newland et al. 2007), and the authors themselves note that the aim of the exercise was to see what archaeological methods could contribute to the understanding of a modern object about which so much could already be assumed to be known. And while the project did, in fact, draw on both documentary and oral accounts in addition to archaeological evidence, the perceived need to justify such work has tended to force a focus on 
field-based archaeological methods fairly narrowly defined in exploring what is most distinctive about contemporary archaeology in and of itself (see further discussion in Harrison 2011).

Nonetheless, there are a number of more recent examples of work on the archaeology of the contemporary world that that do take a strong multisource approach. Laura McAtackney's (2014) work on the Long Kesh Maze Prison provides one example, weaving together and weighing against each other a range of documentary, oral historical, photographic, artefactual, and architectural source materials to explore the recent history and contemporary legacy of one of the most contentious material legacies of the Northern Irish Troubles. Her work on the prison and on associated sectarian landscapes has allowed her to interrogate and reinterpret the histories of the material realities of the Northern Irish peace process (McAtackney 2011, 2013). In some cases, it has also been possible to apply similar multisource approaches in contexts where documentary sources could be perceived to be extremely inaccurate, unrepresentative, or even nonexistent. In their programmatic outline of themes for an archaeology of the contemporary world, Buchli and Lucas emphasized the role which such an archaeology might play in foregrounding those aspects of contemporary life at the margins that are constantly being overwritten by dominant narratives:

In addressing the issue of the non-discursive realm the archaeological act comes directly into contact with the subaltern, the dispossessed and the abject. This is not simply in terms of the usual archaeological preoccupation with material remains, but the practical and social act of uncovering that which has once been hidden. The two converge here both literally and figuratively (Buchli \& Lucas 2001b, p. 14).

Here there has been, perhaps, a greater emphasis on integrating archaeology and ethnography than in historical archaeology as it is generally practiced in Anglophone contexts. An example is the work of Jason De Léon and colleagues as part of the "Undocumented Migration Project", which 
applies archaeological, ethnographic, and forensic methodologies to explore contemporary, undocumented migration flows in the Sonoran Desert of southern Arizona, northern Mexican border towns, and the southern Mexico-Guatemala border (De Léon 2012, 2013, 2015, Gokee \& De Léon 2014, De Léon et al. 2015). Similarly, recent projects on the archaeology of contemporary homelessness on both sides of the Atlantic (e.g. Kiddey 2014a, 2014b, Kiddey \& Schofield 2011, Zimmerman 2013, Zimmerman \& Welch 2011, Zimmerman et al. 2010) also employ strong multisource approaches to understanding questions of social inequality. Rachael Kiddey's work is particularly noteworthy in this regard, drawing closely on oral accounts and collaborative archaeological surface mapping and excavation of "homeless sites" with the assistance of homeless colleagues in Bristol and York (in the UK). As we have already noted, these projects show strong resonances with themes that have long interested historical archaeologists: in the cases above, questions of identity, conflict, and sectarianism, and the inequalities of capitalist economies, respectively.

Another strong area of synergy is between archaeologies of the contemporary world and the subfield of archaeological ethnography. This concerns not only the methodological questions we have pointed to above in relation to a focus on particular forms of source materials, but also the ways in which each have engaged critically with archaeology as a process. Archaeological ethnography is defined by Hamilakis (2011, see also González-Ruibal 2014, Hamilakis \& Anagnostopoulos 2009a, 2009b, Meskell 2005, 2012) as reflexively attuned to the multi-temporal and durational qualities of material objects and their embeddedness within networks of social relations. Like the archaeology of the contemporary world, it shows a concern for the ways in which archaeology is itself co-productive of the pasts and presents it studies (see Dawdy 2010, Lucas 2004, 2005, 2006, 2010, Olivier 2004, 2008, Olsen 2010, Olsen et al 2012, Pearson \& Shanks 2001, Shanks 2012). The relationship between archaeology and modernist, linear conceptions of timeboth as a discipline which is productive of this sense of time, as well as through its use as a 
metaphor for scientific investigation more generally (e.g. see papers in González-Ruibal 2013, Thomas 2004) — is challenged and problematized by an archaeological engagement with the present (Dawdy 2010, Harrison 2011, Lucas 2005, see further discussion below) as much as it is by the subfield of archaeological ethnography (c.f. Hamilakis 2011, p. 409).

It is perhaps no coincidence that many working within the subfield of archaeologies of the contemporary world have thus undertaken research on the archaeology of archaeology itself. Edgeworth's (2003, 2012a, 2012b) and others' (see papers in Edgeworth 2006, Yarrow 2003) work on the ethnography of archaeology here overlaps partially with both archaeological ethnography and archaeologies of the contemporary in applying material-led ethnographic observation to archaeological field and laboratory work. The Ford Transit Van in the "Van" project, mentioned above, had been used by archaeologists at the Ironbridge Gorge site over the period 1989-95 (Bailey et al. 2009). Holtorf's $(2005,2007)$ work on archaeology and popular culture explores the material manifestations of archaeological research within a late modern experience economy (see also Schofield 2009 on the archaeology of the former English Heritage headquarters). Morgan and Eddisford (2015) have recently explored the archaeology of dig houses, Wickstead and Barber (2015) the use of concrete in the restoration of megalithic sites at Stonehenge and Avebury in the UK, and Byrne (2007), Hall (2005, Hall \& Bombardella 2005, 2007), Harrison (2013a) and Holtorf (2012) on the archaeology of contemporary heritage and heritage-related entertainment sites. Such work seems to be a logical extension both of a strong consciousness of the ways in which archaeology functions as a form of knowledge production about the past in the present (see also Olsen et al 2012, Pearson \& Shanks 2001, Shanks 2012), and a broadly ethnographic, sometimes autoethnographic (e.g. Ulin 2009, Edgeworth 2012a, Harrison \& Schofield 2009) engagement with archaeological practices and with the role of archaeology in a late-modern experience society. 
The question of the relationship between the archaeology of the contemporary world and time introduced above bears further consideration. Traditionally, the discipline has been equated with excavation and the quest for deeply layered linear stratigraphies to reveal the material vestiges of ancient civilizations. This view that archaeology is necessarily the "discipline of the spade" (Olsen et al. 2012, p. 61) and should be concerned with a distant past could be argued to be based on an assumption that the past is both hidden and disconnected - physically, chronologically and ontologically - from the present (and indeed the future) and that it is the archaeologist's job to make it resurface in the present (Thomas 2004, 2009, see also Olsen \& Svestad 1994, Harrison 2011, Shanks et al. 2004, but see Edgeworth 2012a, 2013 and discussions in González-Ruibal 2013). This is in turn based on the modern view that historical time is linear and composed of an orderly sequence of isolated past events that do not overlap with any other moments in time, and which are separate to the present (Witmore 2013). Many archaeologists of the contemporary world would tend to argue, drawing on the work of Alfred Whitehead, Henri Bergson and others, that these pasts are never truly "over", as they deposit themselves within all successive presents (e.g. Dawdy 2016, Domanska 2006, González-Ruibal 2006, 2016, Lucas 2005, 2010, Olivier 2004, 2013, Witmore 2006, 2013).

Take for example the site of the Battle of Boquerón, Paraguay, where some of the bloodiest fighting took place during the Chaco War in 1932. Although no longer an active battlefield, the physical space did not magically disappear once fighting had ceased. Instead, it persists as a material entity that both human and non-human actors continue to engage with over time, and these various pasts are imminent and bound together in its material duration (see Breithoff 2013). A battlefield - or indeed any other site, landscape or object - is thus no frozen time capsule of one specific event that took place at one precise moment in time. Instead it is multi- or pluri-temporal (Olivier 2004, p. 205, Olsen et al. 2012, p. 145, Witmore 2006, 2013) and as such is composed of material memories 
from multiple pasts that link situations that occurred centuries apart in the present (Olivier 2013, p. 171). This issue emerges acutely, for example, in Hamilakis' (2009a) discussion of the Greek Civil War (1946-1949) exile island of Makronisos, which was branded by the regime "The New Parthenon", and was filled with replicas of archaeological monuments. Building these replicas was part of the "rehabilitation" project to which left wing exiles were subjected. Here is an example of a case in which contemporary archaeology might be productively and creatively connected with classical archaeology in understanding the ways in which classical pasts are drawn on, and caught up within, more recent ones.

If the past is always encompassed within the present, archaeology might thus be understood to be purely concerned with the present and not really with the past at all (e.g. Olivier 2013). Debates relating to the usefulness of the designation of a "contemporary past" (e.g. Harrison 2011, Holtorf \& Piccini 2009, Voss 2010), responding to the title of Buchli and Lucas' (2001a) formative edited collection, have raised these issues particularly acutely (see González-Ruibal 2013, Witmore 2013). Here, tensions emerge between those who emphasize a more presentist view of the discipline (e.g. Holtorf 2010; Olivier 2013) and others who have adopted a more multi-or pluri-temporal understanding of archaeology (e.g. Hamilakis 2013; Witmore 2013). This is a crucial distinction, and it opens up another domain of inquiry: the entanglement and articulation amongst different times, a theme that connects contemporary archaeology with the discussions of material memory and the politics of the past in the acknowledgement that the efficacy and the political importance of material traces often derives from the fact that they enact different times simultaneously. The concept of the "present" or the "contemporary" emerges from these discussions not so much as a chronological category as a spatial and an ontological one (see Harrison et al. 2014). Some have thus called for archaeologies "in and of the present" (after Harrison 2011, see also Graves-Brown et al. 2013b, Holtorf \& Piccini 2009) or archaeologies which work with a Benjaminian conception of the "now" (e.g. see discussions in Dawdy 2009, 2010, 2016, Harrison 2011) which are neither 
physically nor conceptually restricted by notions of successive, linear time. Free from such confines, archaeologies of the contemporary world might turn their attention to the spaces in which various pasts, whether durational, recurring, or discontinuous, reveal (or are made to reveal) themselves (Harrison 2011, p. 154, see also Pétursdóttir \& Olsen 2014b). Debates regarding the appropriate chronological focus for an archaeology of the contemporary world thus raise more than questions of the demarcation of temporal "turf" between different subfields of archaeology, but also its appropriate focus and subject.

González-Ruibal's (2008) powerful and influential discussion of an archaeology of the contemporary world as an archaeology of "supermodernity" is a good example of the ways in which periodization (c.f. Orser 2013), chronology and focus are interconnected. He argues that the role of the archaeology of the contemporary world should be to emphasize modernity as an "unfinished project" by drawing attention to its fragile underpinnings. In González-Ruibal's work, ruin becomes a symbol of the failure of the modernist project, and drawing attention to ruin forces an engagement with the idea that modernity is not universal or inevitable (see also 2016). Harrison \& Schofield's (2010) discussion of the archaeology of "late modernity" signals a different emphasis, through a focus on "the growth of new communicative technologies and electronic media; the globalization of technology, and its association with altered patterns of production and consumption; the widespread experience of mass migration and the associated rise of transnationalism (in terms of capital, technology, labor, and corporations); new modes of capitalism involving more flexible forms of capital accumulation and distribution; and further growth of availability of leisure time" (p. 2-3). By way of a third example, Graves-Brown's work, which has in many ways focused on exploring the ways in which twentieth and twenty-first century material cultures have mediated what he terms the increasing "privatization of experience" (Graves-Brown 2000c, 2009) and the retreat from public space, has a different emphasis again. 
Perhaps one of the most important issues which has remained sometimes implicit in many of these discussions of emphases, themes and periodizations is whether an archaeology of the contemporary world should be limited to those objects, places and practices which, although recent, have ceased or become abandoned and ruined, or whether such an archaeology might also include objects, sites and material practices which are still functioning or in the process of "becoming". This question is complicated by the work of the "Ruin Memories" project (e.g. see Olsen \& Pétursdóttir 2014, Pétursdóttir 2012, 2013), which shows how even ruins themselves are still active and a part of the present. An acknowledgement of the multi-temporality of the material remains of the past undermines any sense that an archaeology of the contemporary world can confine its object of study only to the abandoned and concluded. Many archaeologies of the contemporary world, on the other hand, have been explicitly concerned with ongoing and emergent socio-material phenomena. White's (2013) work on the Burning Man festival is a good example, as is the work of De León already discussed. Pushing this concern further, Harrison (2016) has recently suggested that archaeologies of the present must concern themselves with documenting and critiquing sociomaterial practices, such as biobanking, which are explicitly concerned with assembling the future.

\section{THE ETHICS AND POLITICS OF ARCHAEOLOGIES OF THE CONTEMPORARY WORLD}

The fact that the human subjects of an archaeology of the contemporary world are, unlike other forms of archaeology which deal with more distant pasts, often still living, provides an urgency to the question of the ethics of such an archaeology (see Graves-Brown et al. 2013b). Archaeological discourse on ethics remains ideologically driven, often dictated by Western ideals of right and wrong (Hamilakis \& Duke 2007). In recent years, it has shifted its focus from a primary concern with the ethical handling of things (especially in relation to illegal or looted antiquities) to the ethical treatment of human beings as stakeholders and human subjects, and an acknowledgement of 
the importance of reflecting on the socio-political setting in which archaeological work is carried out and the impact it has on living communities (see Meskell 2009).

Archaeological engagement with ethics is especially critical in the context of recent violence and its aftermath where it turns "intellectual exercise into a practical necessity” (González-Ruibal \& Moshenska 2015a, p. 1). The temporal, physical and emotional immediacy of recent and/or ongoing conflict has called for an ethics of public engagement (albeit often impossible or undesirable) in order to properly address the interactions between material remains, archaeologists and those afflicted by violence - both dead and alive (witnesses, victims, descendants, perpetrators) (Moshenska 2008, 2015). In their timely edited volume on ethics and recent violence, GonzálezRuibal and Moshenska (2015b) list "the implications of exhuming mass graves (Steele 2008, see Congram 2015; Blau 2015), the responsibilities of archaeologists working in conflict zones (Heinz 2008) and the work with witnesses and victims in situ (Moshenska 2009)"as well as "the destruction and looting of archaeological sites, particularly following the US-led invasion and occupation of Iraq in 2003 (Curtis 2009; Hamilakis 2003, [2009a]; Hollowell 2006)” as ethical considerations thus far discussed in conflict archaeology (González-Ruibal \& Moshenska 2015a, p. 4). In the context of armed conflicts such as the Iraq war, the role of archaeologists as heritage stewards in charge of drafting "no-hit lists" for the invading armed forces raises further questions that are both ethical and epistemological in nature (see Hamilakis 2009b). Should heritage specialists be collaborating with any invading forces at all and if so, can their responsibilities be limited to the safeguarding of archaeological material in the face of immeasurable human suffering? And what makes some things "archaeological" and thus "culturally" worth saving from destruction by the invading armies, and others not? Here, by re-evaluating our traditional understanding of archaeology, contemporary archaeology draws attention not only to the sites and objects of recognized cultural value that escaped the bombings but highlights all the other less conventional but equally locally embedded material culture that did not make it on the list, and as a result may 
have been lost forever (Hamilakis 2009b). Nonetheless, to focus on such "loss" alone seems equally problematic when contemporary archaeologies draw attention to the ways in which material heritages are constantly made and remade in the present. To this we would add that the archaeological debate on research ethics and archaeologies of recent conflict should extend to the researchers themselves as they often undertake research on culturally, politically and socially sensitive topics, which raise additional and multilayered ethical questions.

The development of modern conflict archaeologies (or what has been termed the "archaeology of dictatorship" or "archaeology of repression" (c.f. Funari \& Zarankin 2006, Funari et al. 2009, Zarankin \& Funari 2008, Zarankin \& Salerno 2008) within Latin America provides a clear example of the ways in which archaeologies of the contemporary world might engage with a process of presencing repressed or absent collective and individual social memories and underscores the ways in which the archaeology of the contemporary world cannot, as in the case of archaeology more generally (e.g. Gero et al. 1983, Hamilakis \& Duke 2007, Kohl \& Fawcett 1995), be separated from its politics. Due to the political and social nature of many of these aspects of modern conflict archaeology, González-Ruibal has urged archaeologies of recent violence to go beyond a passive collecting of data and develop a "critical voice” (González-Ruibal 2008, p. 256). Archaeological practice dealing with modern conflicts thus transcends its traditional purpose of digging up old things that have no direct bearing on the present, or indeed the future, as it "serves a different purpose in the recent past, one that is more immediate, socially relevant, and as a consequence tense and often painful” (Buchli \& Lucas 2001b, p. 15). Forensic archaeology especially (e.g. Doretti \& Fondebrider 2001, Ferllini 2007, Haglund et al. 2001, Renshaw 2011, Snow et al. 1984) can also act as a "therapeutic tool" for victims of recent conflict situations as well as their friends and family (Buchli \& Lucas 2001c, p. 173). By materializing hitherto concealed atrocities and hidden voices archaeology uses the power of multi-vocality (Olivier 2001, p. 187) to challenge official versions of 
the past and replace them with alternative narratives and truths (Buchli \& Lucas 2001c, also Funari et al. 2009).

During the second part of the twentieth century many Latin American nations suffered decades of severe human rights abuses under oppressive military regimes. People had to endure years of fear, censorship, false arrests, physical and psychological torture and exile. To eradicate any leftist opposition thousands of people were kidnapped, interrogated and tortured by special police forces in countries such as Guatemala, Mexico, Argentina, Uruguay, Chile and Paraguay. Many of the victims vanished without a trace and became collectively known as the desaparecidos (disappeared); their fate and legal status of "missing" shrouded in vagueness. This ensued in relentless efforts by family members and friends of the desaparecidos to locate their missing loved ones, establish their fate, and name and punish the culprits.

In the 1980s a group of medicine and archaeology students under the training of US forensic anthropologist Clyde Snow formed the EAAF, the Equipo Argentino de Antropología Forense (Argentine Forensic Anthropology Team) with the aim of finding and identifying the victims of Argentina's military dictatorship (ca. 1976-1983) (Crossland 2000, Doretti \& Snow 2003). Since its foundation, the EAAF has extended its boundaries and trained archaeological teams in other countries that had suffered human rights violations under repressive regimes, such as Guatemala, Colombia, Angola, Sierra Leone, Indonesia, Bosnia and Morocco, to name only a few (Snow et al. 1984). The subsequent creation of the ALAF (Asociación Latinoamericana de Antropología Forense/Latin American Association of Forensic Anthropology) in 2003 finally firmly established forensic archaeology as a field in Latin America. It also allowed the field to expand its hitherto purely scientific focal point to encompass a more anthropological research approach and to not only deal with relatives and their quest for truth in a legal setting but to incorporate a social agenda as well (Fondebrider 2009, p. 49). Shortly after, two collections of papers - Historias Desaparecidas. 
Arqueología, Memoria y Violencia Política (Disappeared Histories. Archaeology, Memory and Political Violence) (Zarankin et al. 2012) and Arqueología de la Represión y Resistencia en América Latina 1960-1980 (Funari \& Zarankin 2006) later translated into English as Memories from Darkness: Archaeology of Repression and Resistance in Latin America (Funari et al. 2009) were published and remain the most valuable edited volumes on the archaeology of dictatorship in Latin America (but see also paper by Prieto and Vila 2014).

Zarankin and Salerno's (2008) discussion of archaeologies of repression in Latin America identify the key themes which have emerged from this work, including "theoretical reflections on the archaeology of repression, memory and uses of the past” [(e.g. Funari \& Vieira de Oliveira 2009, Haber 2009, López Mazz 2009)], "the recuperation and identification of the remains of disappeared persons” [e.g. López Mazz 2009, Perosino 2012)], “the study of clandestine detention centres” [(e.g. Bianchi et al. 2012, Di Vruno 2012, San Francisco et al. 2012, Zarankin \& Niro 2009)], "the analysis of objects associated with repression” [(López Mazz 2009, Navarrete Sánchez \& López 2009, Salerno 2009)], and “emblematic case studies” [(Fournier \& Martínez Herrera 2009, Rodríguez Suárez 2009)] (themes after summary given in Zarankin \& Salerno 2008, p. 25-29, our translation).

\section{CONCLUDING REMARKS: ON THE POTENTIAL FOR ARCHAEOLOGIES OF THE CONTEMPORARY WORLD TO RESHAPE THE FUTURE}

As our discussion of the politics of the archaeology of the contemporary world has already suggested, in reviewing the themes which have been pursued by this subfield, it is quite clear that many have aimed to engage with key contemporary social, economic, political and ecological issues. Work on twentieth and twenty-first century industry (e.g. Stratton \& Trinder 2000); conflict (e.g. González-Ruibal 2008); waste (e.g. Rathje \& Murphy 1992, Reno 2013); the Anthropocene (e.g. Edgeworth et al. 2014); protest (e.g. Badcock \& Johnson 2013, Beck et al. 2007, 2009, 
Marshall et al. 2009, Schofield \& Anderton 2000); processes of ruin, ruin "porn" and urban decay/regeneration (e.g. Lucas 2013, Olsen \& Pétursdóttir 2014, Pétursdóttir \& Olsen 2014a, Ryzewski 2015, Schofield \& Morrissey 2013); deindustrialization (e.g. Penrose 2007, 2010); sectarianism (e.g. McAtackney 2013, 2014); the politics of race and difference (Byrne 2013, Mullins 2013); virtual worlds and new media (e.g. Harrison 2009, Piccini 2015); homelessness (e.g. Buchli \& Lucas 2001d; Crea et al 2014, Zimmerman 2013) and undocumented migration (e.g. De Léon 2016, Hamilakis in press) for example, all reflect a desire to orient the project of an archaeology of the contemporary world towards academic engagements with the present which might have the potential to reshape the future. Many archaeologists (e.g. González-Ruibal 2006, 2008, 2013, Dawdy 2009, 2010, Harrison 2011, 2016, papers in Wurst and Mrozowski 2014) and anthropologists (e.g. Rabinow et al. 2008, Rabinow 2008, 2011, Appadurai 2013) have explicitly called for a critical anthropological engagement with both the contemporary and the global futures which are actively assembled in the present. Whilst there have been some reservations expressed about the ways in which such an explicit orientation towards the needs of "our" human future might produce a biased, or at least anthropocentric orientation to the archaeology of the contemporary world (see Pétursdóttir \& Olsen 2014b), we would suggest there is space both for those approaches which remain attentive and open to the otherness of contemporary materials and other agentive non-humans whilst still considering how they might be engaged as agents of change in a range of present and future issues of ecological, economic, political, and social concern in which both humans and non-humans are implicated. In a world which could be argued to be increasingly "full" of people and "stuff", we are increasingly forced into a selective processing of what we consider to be of archaeological value and thus worthy of preserving in museums and both physical and digital archives. The exponential growth of objects and temporal immediacy of contemporary material culture (see Harrison 2013b) as well as the problems that may arise from it, such as the fragility of digital data storage (Bollmer 2015), e-waste and its negative impact on the environment (Taffel 2015) or the potentially lethal cultural heritage of nuclear waste (Holtorf and Högberg 2014), poses 
a real challenge to heritage and contemporary museology and opens up debate on what should be kept as physical mementoes of our present for future generations, and what form such collections should take.

Almost four decades ago, Rathje suggested the archaeology should be defined as the study of "the interaction between material culture and human behavior or ideas, regardless of time or space" (Rathje 1979, p. 2, our emphasis) and that a move towards the archaeological study of contemporary materials represented "a final step in the transformation of archaeology into a unified, holistic approach to the study of society and its material products" (Rathje 1979, p. 29). This provocation has finally begun to be realized by the subfield which his pioneering work, and the work of his peers, has stimulated. 


\section{LITERATURE CITED}

Alberti B. 2016. Archaeologies of Ontology. Annual Review of Anthropology 45:163-179

Andreassen E, Bjerck H, Olsen B. 2010. Persistent Memories: Pyramiden - A Soviet Mining Town in the High Arctic. Trondheim: Tapir Press

Appadurai, A. 2013. The Future as Cultural Fact: Essays on the Global Condition. London, UK: Verso

Badcock A, Johnston R. 2013. Protest. In The Oxford Handbook of the Archaeology of the Contemporary World, ed. P Graves-Brown, R Harrison, A Piccini, pp. 321-335. Oxford/New York: Oxford University Press

Bailey G, Newland C, Nilsson A, Schofield J. 2009. Transit, Transition: Excavating J641 VUJ. Cambridge Archaeological Journal 19 (1):1-27

Beaudry MC. ed. 1988. Documentary Archaeology in the New World (New Directions in Archaeology). Cambridge, UK: Cambridge University Press

Beaudry MC. 1995. Introduction: Ethnography in Retrospect. In The Written and the Wrought: Complementary Sources in Historical Anthropology, ed. M. E. D’Agostino, E.Prine, E. Casella, M. Winer, pp. 1-16. Berkeley: Kroeber Anthropological Society Papers No. 79. Department of Anthropology, University of California

Beck C, Drollinger H, Schofield J. 2007. The archaeology of Peace Camp, Nevada. In A Fearsome Heritage, ed. J Schofield, W Cocroft, pp. 297-320. London/New York: Routledge

Beck C, Drollinger H, Schofield J. 2009. Archaeologists, activists and a contemporary peace camp. In Contemporary Archaeologies: Excavating Now, ed. A Piccini, C Holtorf, pp. 95-112. Bern: Peter Lang

Bianchi S, Angelo N, Baster J, Biani M, Brugé L, Carunchio L, Compañy G, Franco M, González G, Loja F, Fapalardo C, Quemada L, Roda L, Román R, Rossetto D, Rubio JA. (2012). De las indentidades políticas...A la construcción de la memoria colectiva. In Historias Desaparecidas. Arqueología, memoria y violencia política, ed. A Zarankin, MA Salerno, MC Perosino, pp. 91-100. Córdoba: Encuentro Grupo Editor/Facultad de Humanidades, Universidad Nacional de Catamarca

Binford L. 1967. Smudge Pits and Hide Smoking: The Use of Analogy in Archaeological Reasoning. American Antiquity 32:1-12

Binford L. 1978. Nunamuit Ethnoarchaeology. New York: Academic Press

Blau S. 2015. Working as a Forensic Archaeologist and/or Anthropologist in Post-Conflict Contexts: A Consideration of Professional Responsibilities to the Missing, the Dead and their Relatives. In Ethics and the Archaeology of Violence, ed. A González-Ruibal, G Moshenska, pp. 215-228. New York: Springer

Bollmer G. 2015. Fragile Storage, Digital Futures. Journal of Contemporary Archaeology 2(1);6672 
Breithoff E. 2013. Fortín Boquerón: a conflict landscape past and present. Revista Cadernos do Ceom 26(38): 65-84

Buchli V. 2002. Introduction. In The Material Culture Reader, ed. V. Buchli, pp. 1-22. New York/London: Berg

Buchli V, Lucas G, eds. 2001a. Archaeologies of the Contemporary Past. London/New York: Routledge

Buchli V, Lucas G. 2001b. The absent present. Archaeologies of the contemporary past. In Archaeologies of the Contemporary Past, ed. V Buchli, G Lucas, pp. 3-18. London/New York: Routledge

Buchli V, Lucas G 2001c. Presencing Absence. In Archaeologies of the Contemporary Past, ed. V Buchli, G Lucas, pp. 171-174. London/New York: Routledge

Buchli V, Lucas G. 2001d. The Archaeology of Alienation: A Late Twentieth-Century British Council House. In Archaeologies of the Contemporary Past, ed. V Buchli, G Lucas, pp. 158-67. London/New York: Routledge

Burström M. 2012. Treasured Memories: Tales of buried belongings in wartime Estonia. Lund: Academic Press

Burström M, Gustafsson A, Karlsson H. 2011. World Crisis in Ruin: The Archaeology of the Former Soviet Nuclear Missile Sites in Cuba. Lindome: Bricoleur Press

Byrne D. 2007. Surface Collection: Archaeological Travels in Southeast Asia. Lanham, MD: AltaMira Press

Cabak, MA, Groover MD, Inkrot MM. 1999. Rural Modernization During the Recent Past: Farmstead Archaeology in the Aiken Plateau. Historical Archaeology 33(4):19-43

Congram D. 2015. Cognitive Dissonance and the Military-Archaeology Complex. In Ethics and the Archaeology of Violence, ed. A González-Ruibal, G Moshenska, pp. 199-214. New York: Springer.

Crea G, Dafnis A, Hallam J, Kiddey R, Schofield J. 2014. Turbo Island, Bristol: excavating a contemporary homeless place. Journal of Post Medieval Archaeology 48(1):133-150

Crossland Z. 2000. Buried Lives: Forensic Archaeology and the Disappeared in Argentina. Archaeological Dialogues 7(2):146-159

Crossland Z. 2011. The archaeology of contemporary conflict. In The Oxford handbook of the archaeology of ritual and religion, ed. T Insoll, pp. 285-306. Oxford/New York: Oxford University Press

Croucher SK, Weiss L, eds. 2011. The Archaeology of Capitalism in Colonial Contexts: Postcolonial Historical Archaeologies. New York: Springer

Curtis J. 2009. Relations between archaeologists and the military in the case of Iraq. Papers from the Institute of Archaeology, 19: 2-8 
David N, Kramer C. 2001. Ethnoarchaeology in Action. Cambridge/New York: Cambridge University Press

Dawdy SL. 2009. Millennial archaeology. Locating the discipline in the age of insecurity. Archaeological Dialogues 16(2):131-42

Dawdy SL. 2010. Clockpunk anthropology and the ruins of modernity. Current Anthropology 51(6), 761-93

Dawdy SL. 2016. Patina: A Profane Archaeology. Chicago, IL: University of Chicago Press

De León J. 2012. "Better to be Hot Than Caught": Excavating the Conflicting Roles of Migrant Material Culture. American Anthropologist 114(3):477-495

De León J. 2013. Undocumented Migration, Use-Wear, and the Materiality of Habitual Suffering in the Sonoran Desert. Journal of Material Culture 18(4):1-32

De León J. 2015. The Land of Open Graves: Living and Dying on the Migrant Trail. Oakland: University of California Press

De León J, Gokee C, Schubert A. 2015. "By the Time I Get to Arizona": Citizenship, Materiality, and Contested Identities Along the US-Mexico Border. Anthropological Quarterly 88(2):445-479

Di Vruno A 2012. La praxis arqueológica. El caso Mansión Seré. In Historias Desaparecidas. Arqueología, memoria y violencia política, ed. A Zarankin, MA Salerno, MC Perosino, pp. 101116. Córdoba: Encuentro Grupo Editor/Facultad de Humanidades, Universidad Nacional de Catamarca

Domanska E. 2006. The material presence of the past. History and Theory 45:337-48

Doretti M, Fondebrider L. 2001. Science and human rights: truth, justice, reparation and reconciliation, a long way in Third World countries. In Archaeologies of the Contemporary Past, ed. V Buchli, G Lucas, pp. 138-144. London/New York: Routledge

Doretti M, Snow C. 2003. Forensic Anthropology and Human Rights: The Argentine Experience. In Hard Evidence: Case Studies in Forensic Anthropology, ed. DW Steadman, pp. 290-310. New Jersey: Prentice Hall.

Edgeworth M. 2003. Acts of Discovery: an ethnography of archaeological practice. BAR International Series 1131. Oxford, UK: Archaeopress

Edgeworth M, ed. 2006. Ethnographies of Archaeological Practice: Cultural Encounters, Material Transformations Worlds of Archaeology. Lanham, MD: Altamira Press

Edgeworth M. 2012a. Follow the cut, follow the rhythm, follow the material. Norwegian Archaeological Review 45(1):76-114

Edgeworth M. 2012b. Fields of artefacts: archaeologies of contemporary scientific discovery. In Studies in Contemporary and Historical Archaeology Modern Materials: The proceedings of CHAT Oxford, 2009, ed. B Fortenberry L McAtackney, pp. 7-12. Oxford, UK: Archaeopress. 
Edgeworth M. 2013. The Clearing: Archaeology's way of opening the world. In Reclaiming Archaeology: Beyond the Tropes of Modernity, ed. A González-Ruibal, pp. 33-43. London/New York: Routledge

Edgeworth M, Benjamin J, Clarke B, Crossland Z, Domanska E, Gorman AC, Graves-Brown P, Harris EC Hudson MJ, Kelly JM, Paz VJ, Salerno MA, Witmore C, Zarankin A. 2014. Archaeology of the Anthropocene. Journal of Contemporary Archaeology 1(1):73-132

Ferllini, R, ed. 2007. Forensic Archaeology and Human Rights Violations. Springfield, IL: Charles C. Thomas

Fewster K. 2007. The role of agency and material culture in remembering and forgetting: An ethnoarchaeological case study from Central Spain. Journal of Mediterranean Archaeology 20:89114

Fewster K. 2013. The Relationship between Ethnoarchaeology and Archaeologies of the Contemporary Past: A Historical Investigation. In The Oxford Handbook of the Archaeology of the Contemporary World, ed. P Graves-Brown, R Harrison, A Piccini, pp. 27-39. Oxford/New York: Oxford University Press

Finn C. 2001. Artifacts: An archaeologist's year in Silicon Valley. Cambridge, MA: MIT Press

Flexner JL. 2016. Ethnology collections as supplements and records: what museums contribute to historical archaeology of the New Hebrides (Vanuatu). World Archaeology 48(2):196-209

Fondebrider L. 2009. Forensic Archaeology and Anthropology: A Balance Sheet. In Memories from Darkness: Archaeology of Repression and Resistance in Latin America, ed. PPA Funari, A Zarankin, MA Salerno, pp. 47-56. New York/London: Springer

Fortenberry B, McAtackney L, eds. 2012. Modern Materials: The proceedings of CHAT Oxford, 2009. Oxford, UK: Archaeopress

Fortenberry B, Myers A, eds. 2010. Perspectives on the Recent Past. Archaeologies 6(1):1-192

Fournier P, Martínez Herrera J. 2009. "Mexico, 1968": Among Olympic Fanfares, Government Repression and Genocide. In Memories from Darkness: Archaeology of Repression and Resistance in Latin America, ed. PPA Funari, A Zarankin, MA Salerno, pp 145-174. New York/London: Springer

Funari, PPA, Vieira de Oliveira N. 2009. The Archaeology of Conflict in Brazil. In Memories from Darkness: Archaeology of Repression and Resistance in Latin America, ed. PPA Funari, A Zarankin, MA Salerno, pp 25-32. New York/London: Springer

Funari PPA, Zarankin A, eds. 2006. Arqueología de la Represión y Resistencia en America Latina 1960-1980. Madrid: Ediciones Encuentro

Funari PPA, Zarankin A, Salerno MA. eds. 2009. Memories from Darkness: Archaeology of Repression and Resistance in Latin America. New York/London: Springer.

Gero JM, Lacy DM, Blakey ML, eds. 1983. The Socio-politics of Archaeology. Amherst, MA: University of Massachusetts 
Gokee C, De León J. 2014. Sites of Contention: Archaeological Classification and Political Discourse in the US-Mexico Borderlands. Journal of Contemporary Archaeology 1(1):133-163

González-Ruibal A., 2003. La experiencia del otro: una introducción a la etnoarqueología. Ediciones Akal

González-Ruibal A. 2006. The Past is Tomorrow: Towards an Archaeology of the Vanishing Present. Norwegian Archaeological Review 39(2):110-125

González-Ruibal A. 2008. Time to Destroy: Towards an Archaeology of Supermodernity. Current Anthropology 49(2):247-279

González-Ruibal A. 2013. Reclaiming Archaeology. In Reclaiming Archaeology: Beyond the Tropes of Modernity, ed. A González-Ruibal, pp. 1-30. Abingdon/New York: Routledge

González-Ruibal A. 2014. An Archaeology of Resistance: Materiality and Time in an African Borderland. Lanham, MD: Rowman \& Littlefield Publishers

González-Ruibal A. 2016. Archaeology and the Time of Modernity. Historical Archaeology 50(3):144-164.

González-Ruibal A, Harrison R, Holtorf C, Wilkie L. 2014. Archaeologies of Archaeologies of the Contemporary Past: An Interview with Victor Buchli and Gavin Lucas. Journal of Contemporary Archaeology 1(2):265-276

González-Ruibal A, Hernando A, Politis G. 2010. Ontology of the self and material culture: Arrowmaking among the Awá hunter-gatherers (Brazil). Journal of Anthropological Archaeology 30(1):1-16

González-Ruibal A, Moshenska G, eds. 2015a. Introduction: The Only Way is Ethics. In Ethics and the Archaeology of Violence, ed. A González-Ruibal, G Moshenska, pp. 1-17. New York: Springer

González-Ruibal A, Moshenska G, eds. 2015b. Ethics and the Archaeology of Violence. New York: Springer

Gould RA. 1980. Living Archaeology. Cambridge/NewYork: Cambridge University Press

Gould RA. 2007. Disaster Archaeology. Salt Lake City, UT: University of Utah Press

Gould RA, Schiffer MB, eds. 1981. Modern Material Culture: The Archaeology of Us. New York: Plenum Publishers

Graves-Brown P, ed. 2000a. Matter, Materiality and Modern Culture. London/New York:

Routledge

Graves-Brown P. 2000b. Introduction. In Matter, Materiality and Modern Culture, ed. P GravesBrown, pp. 1-9. London/New York: Routledge

Graves-Brown P. 2000c. Always Crashing in the Same Car. In Matter, Materiality and Modern Culture, ed. P Graves-Brown, pp. 156-165. London/New York: Routledge 
Graves-Brown P. 2009. The Privatisation of Experience and the Archaeology of the Future. In Contemporary Archaeologies: Excavating Now, eds. C Holtorf, A Piccini, pp. 201-213. Bern: Peter Lang

Graves-Brown P, Harrison R, Piccini A, eds. 2013a. The Oxford Handbook of the Archaeology of the Contemporary World. Oxford/New York: Oxford University Press

Graves-Brown P, Harrison R, Piccini A. 2013b. Introduction. In The Oxford Handbook of the Archaeology of the Contemporary World, ed. P Graves-Brown, R Harrison, A Piccini, pp. 1-23. Oxford/New York: Oxford University Press

Haber AF. 2009. Torture, Truth, Repression and Archaeology. In Memories from Darkness: Archaeology of Repression and Resistance in Latin America, ed. PPA Funari, A Zarankin, MA Salerno, pp 3-8. New York/London: Springer

Haglund WD, Connor M, Scott DD. 2001. The archaeology of contemporary mass graves. Historical Archaeology 35(1):57-69

Hall M. 2000. Archaeology and the Modern World: Colonial Transcripts in South Africa and the Chesapeake. London/New York: Routledge

Hall M. 2005. The industrial archaeology of entertainment. In Industrial Archaeology: Future Directions, ed. EC Casella, J Symonds, (pp. 261-278). New York: Kluwer/Plenum

Hall M, Bombardella P. 2005. Las Vegas in Africa. Journal of Social Archaeology 5(1):5-24

Hall M, Bombardella P. 2007. Paths of Nostalgia and Desire through Heritage Destinations at the Cape of Good Hope. In Desire lines: space, memory and identity in the post-apartheid city, ed. N Murray, N Shepherd, M Hall. London/New York: Routledge

Hall M, Silliman SW. 2006. Introduction: Archaeology of the Modern World. In Historical Archaeology, ed. M Hall, SW Silliman, pp. 1-19. Malden, MA : Blackwell

Hamilakis Y. 2003. Iraq, stewardship and "the record:" An ethical crisis for archaeology. Public Archaeology 3:104-111

Hamilakis Y. 2009a. The Nation and its Ruins: Antiquity, Archaeology, and National Imagination in Greece. Oxford and New York: Oxford University Press.

Hamilakis Y. 2009b. "The "War on Terror" and the Military-Archaeology Complex: Iraq, Ethics, and Neo-Colonialism." Archaeologies 5(1):39-65

Hamilakis Y. 2011. Archaeological Ethnography: A Multitemporal Meeting Ground for Archaeology and Anthropology. Annual Review of Anthropology 40:399-414

Hamilakis Y. 2013. Archaeology and the Senses: Human Experience, Memory, and Affect. Cambridge and New York: Cambridge University Press.

Hamilakis Y, 2016. Archaeologies of Forced and Undocumented Migration. Journal of Contemporary Archaeology 3(3). In press 
Hamilakis Y, Duke P, eds. 2007. Archaeology and Capitalism: From Ethics to Politics. Walnut Creek, CA: Left Coast Press.

Hamilakis Y, Anagnostopoulos A, eds. 2009a. Archaeological Ethnographies. Public Archaeologies $8(2 \& 3)$

Hamilakis Y, Anagnostopoulos A. 2009b. What is archaeological ethnography?. Public Archaeology, 8(2\&3):65-87

Harrison R. 2009. Excavating Second Life: Cyber-Archaeologies, Heritage and Virtual Communities. Journal of Material Culture 14(1):75-106

Harrison R. 2011. Surface Assemblages: Towards an Archaeology in and of the Present. Archaeological Dialogues 18(2):141-196

Harrison R. 2013a. Heritage. In The Oxford Handbook of the Archaeology of the Contemporary World, ed. P Graves Brown, R Harrison, A Piccini, pp. 273-288. Oxford, UK: Oxford University Press

Harrison R. 2013b. Forgetting to remember, remembering to forget: Heritage, late modernity and the 'problem' of memory. International Journal of Heritage Studies 19(6): 579-595.

Harrison R. 2016. Archaeologies of Emergent Presents and Futures. Historical Archaeology 50(3):165-180

Harrison R, Schofield J. 2009. Archaeoethnographies/Autoarchaeologies: Introducing Archaeologies of the Contemporary Past. Archaeologies 5(2):185-360.

Harrison R, Schofield J. 2010. After Modernity: Archaeological Approaches to the Contemporary Past. Oxford/New York: Oxford University Press

Harrison R, Wilkie L, González-Ruibal A, Holtorf C. 2014. Editorial. Journal of Contemporary Archaeology 1(1):1-6

Heinz M. 2008. Archaeological research in conflict areas: Practice and responsibilities. Archaeologies 4(3):460-470.

Hicks D. 2010. The Material-Cultural Turn: Event and Effect. In The Oxford Handbook of Material Culture Studies, ed. D Hicks, MC Beaudry, pp. 25-98. Oxford/New York: Oxford University Press

Hodder I. 1987. Bow ties and pet foods. Material culture and change in British Industry. In The Archaeology of Contextual Meanings, ed. I Hodder, pp. 11-19. Cambridge/New York: Cambridge University Press

Hollowell J. 2006. Moral arguments on subsistence digging. In The ethics of archaeology: Philosophical perspectives on archaeological practice, ed. C Scarre, G Scarre, pp. 69-93. Cambridge, UK: Cambridge University Press

Holtorf C. 2005. From Stonehenge to Last Vegas: Archaeology as Popular Culture. Lanham: AltaMira Press. 
Holtorf C. 2007. Archaeology is a Brand! The Meaning of Archaeology in Contemporary Popular Culture. Walnut Creek: Left Coast Press

Holtorf C. 2010. Search the Past - Find the Present. The Value of Archaeology for Present-day Society. Amsterdam: Erfgoed Nederland

Holtorf, C. 2012. The Heritage of Heritage. Heritage \& Society 5(2): 153-173.

Holtorf C, Högberg, A. 2014. Communicating with future generations: What are the benefits of preserving for future generations? Nuclear power and beyond. The European Journal of PostClassical Archaeologies 4:315-330

Holtorf C, Piccini A, eds. 2009. Contemporary Archaeologies: Excavating Now. Bern: Peter Lang

Kiddey R. 2014a. Homeless Heritage: collaborative social archaeology as therapeutic practice. PhD thesis, University of York, York, UK

Kiddey R. 2014b. Punks and Drunks: Counter Mapping Homelessness in Bristol and York. In Who Needs Experts? Counter Mapping Cultural Heritage, ed. J Schofield, pp. 165-179. Farnham, UK: Ashgate Publishing Limited

Kiddey R, Schofield J. 2011. Embrace the Margins: Adventures in Archaeology and Homelessness. Public Archaeology 10(1):4-22

Kohl PL, Fawcett C. 1995. Nationalism, politics and the practice of archaeology. Cambridge, UK: Cambridge University Press

Leone MP. 1973. Archeology as the Science of Technology: Mormon Town Plans and Fences. In Research and Theory. In Current Archeology, ed. CL Redman, pp. 125-150. New York: John Wiley and Sons

Leone MP. 2005. The Archaeology of Liberty in an American Capital: Excavations in Annapolis Berkeley: University of California Press

Leone MP. 2009. Making Historical Archaeology Postcolonial. In International Handbook of Historical Archaeology, ed. T Majewski, D Gaimster, pp. 159-68. New York: Springer

Leone, MP, Potter Jr PB, eds. 1999. Historical Archaeologies of Capitalism. New York: Springer

López Mazz, JM 2009. An Archaeological View of Political Repression in Uruguay (1971-1985). In Memories from Darkness: Archaeology of Repression and Resistance in Latin America, ed. PPA Funari, A Zarankin, MA Salerno, pp 33-46. New York/London: Springer

Lucas G. 2004. Modern Disturbances: On the Ambiguities of Archaeology. Modernism/modernity 11(1):109-20.

Lucas G. 2005. The Archaeology of Time. London/New York: Routledge

Lucas G. 2006. Historical Archaeology and Time. In The Cambridge Companion to Historical Archaeology, ed. D Hicks, MC Beaudry, pp. 34-47. Cambridge/New York: Cambridge University Press 
Lucas G. 2010. Time and the archaeological archive. Rethinking History 14:343-59.

Lucas G. 2013. Ruins. In The Oxford Handbook of the Archaeology of the Contemporary World, ed. P Graves Brown, R Harrison, A Piccini, pp. 192-203. Oxford, UK: Oxford University Press

Lydon J. 2009. Fantastic Dreaming: The Archaeology of an Aboriginal Mission. Lanham, MD: AltaMira Press

Marshall Y, Roseneil S, Armstrong K. 2009. Situating the Greenham Archaeology: An Autoethnography of a Feminist Project. Public Archaeology 8(2-3):225-45

Matthews CN. 2010. The Archaeology of American Capitalism. Gainesville, FL: University of Florida Press

May S, Orange H, Penrose S. 2012. The Good, the Bad and the Unbuilt: Handling the Heritage of the Recent Past. Oxford, UK: Archaeopress

McAtackney L. 2011. Peace maintenance and political messages: The significance of walls during and after the Northern Irish 'Troubles'. Journal of Social Archaeology 11(1):77-98

McAtackney L. 2013. Sectarianism. In The Oxford Handbook of the Archaeology of the Contemporary World, ed. P Graves Brown, R Harrison, A Piccini, pp. 232-246. Oxford, UK: Oxford University Press

McAtackney L. 2014. An Archaeology of the Troubles: The dark heritage of Long Kesh/Maze prison. Oxford/New York: Oxford University Press

McAtackney L, Palus M, Piccini A, eds. 2007. Contemporary and Historical Archaeology in Theory. Papers from the 2003 and 2004 CHAT Conferences. Oxford, UK: Archaeopress

McAtackney L, Penrose S. 2016. The contemporary in post-medieval archaeology, Post-Medieval Archaeology 50(1):148-158

McGuire RH, Paynter R, eds. 1991. The Archaeology of Inequality. Blackwell, Oxford

Meskell L. 2005. Archaeological Ethnography: Conversations around Kruger National Park. Archaeologies 1(1):81-100

Meskell L. 2009. Introduction: Cosmopolitan heritage ethics. In Cosmopolitan archaeologies, ed. L Meskell, pp. 1-27. London, UK: Duke University Press

Meskell L. 2012. Archaeological Ethnography: Materiality, Heritage and Hybrid Methodologies. In Archaeology and Anthropology: Past, Present and Future, ed. D Shankland, pp. 133-144. London, $\mathrm{UK}$ : Berg

Miller D. 1987. Material Culture and Mass Consumption. Oxford, UK: Basil Blackwell

Miller D. 1994. Modernity - An Ethnographic Approach: Dualism and mass consumption in Trinidad. Oxford, UK: Berg

Miller D. 1998. A Theory of Shopping. Cambridge, UK: Polity Press/Cornell University Press 
Moore H. 1986. Space, Text and Gender: An Anthropological Study of the Marakwet of Kenya. Cambridge, UK: Cambridge University Press

Morgan C, Eddisford, D. 2015. Dig Houses, Dwelling, and Knowledge Production in Archaeology. Journal of Contemporary Archaeology 2(1):169-193

Moshenska G. 2008. Ethics and ethical critique in the archaeology of modern conflict. Norwegian Archaeological Review 41(2):159-175

Moshenska G. 2009. Contested pasts and community archaeologies: Public engagement in the archaeology of modern conflict. In Europe's deadly century: Perspectives on 20th century conflict heritage, ed. N Forbes, R Page, G Pérez, pp. 73-79. London, UK: English Heritage

Moshenska G. 2013. Conflict. In The Oxford Handbook of the Archaeology of the Contemporary World, ed. P Graves-Brown, R Harrison, A Piccini, pp. 351-363. Oxford/New York: Oxford University Press

Moshenska G. 2015. The Ethics of Public Engagement in the Archaeology of Modern Conflict. In Ethics and the Archaeology of Violence, ed. A González-Ruibal, G Moshenska, pp. 167-180. New York: Springer.

Mullins PR. 1999. Race and Affluence: An Archaeology of African America and Consumer Culture. New York: Plenum

Mullins PR. 2010. Race and Class. In Handbook of Postcolonial Archaeology, ed. J Lydon, UZ Rizvi, pp. 375-85. Walnut Creek, CA: Left Coast Press

Mullins PR. 2013. Race and Prosaic Materiality: The Archaeology of Contemporary Urban Space and the Invisible Colour Line. In The Oxford Handbook of the Archaeology of the Contemporary World, ed. P Graves-Brown, R Harrison, A Piccini, pp. 508-521. Oxford/New York: Oxford University Press

Myers A, Moshenska M, eds. 2011. Archaeologies of Internment. New York: Springer Verlag

Navarrete Sánchez, R, López AM 2009. Scratching Behind the Walls; Graffiti and Symbolic Political Imagination at Cuartel San Carlos (Caracas, Venezuela). In Memories from Darkness: Archaeology of Repression and Resistance in Latin America, ed. PPA Funari, A Zarankin, MA Salerno, pp 105-125. New York/London: Springer

Newland C, Bailey G, Schofield J, Nilsson A. 2007. Sic Transit Gloria Mundi. British Archaeology 92:16-21

Olivier L. 2001. The archaeology of the contemporary past. In Archaeologies of the Contemporary Past, ed. V Buchli, G Lucas, pp. 175-188. London/New York: Routledge

Olivier L. 2004. The past of the present. Archaeological memory and time. Archaeological Dialogues 10(2):204-213

Olivier L. 2008. Le sombre abîme du temps. Archéologie et mémoire. Paris: Seuil

Olivier L. 2013. The Business of Archaeology is the Present. In Reclaiming Archaeology: Beyond the Tropes of Modernity, ed. A González-Ruibal, pp. 117-129. London, UK: Routledge 
Olsen B. 2010. In defense of things: archaeology and the ontology of objects. Lanham, MA/Plymouth, UK: Rowman Altamira

Olsen B, Pétursdóttir P, eds. 2014. Ruin Memories: Materialities, Aesthetics and the Archaeology of the Recent Past. Abingdon/New York: Routledge

Olsen B, Shanks M, Webmoor T, Witmore C. 2012. Archaeology: The Discipline of Things. Berkeley, CA: University of California Press

Olsen B, Svestad A. 1994. Creating prehistory. Archaeology museums and the discourse of modernism, Nordisk Museologi: 3-20

Orange H, ed. 2015. Reanimating Industrial Spaces: Conducting Memory Work in Post-industrial Societies. Walnut Creek, CA: Left Coast Press

Orser CE. 2013. The Politics of Periodization. In Reclaiming Archaeology: Beyond the Tropes of Modernity, ed. A González-Ruibal, pp. 145-154. London, UK: Routledge

Pearson M, Shanks M. 2001. Theatre/Archaeology. London/New York: Routledge

Penrose S. 2007. Images of change. An archaeology of England's contemporary landscape.

Swindon, UK: English Heritage

Penrose S. 2010. Recording Transition in Post-Industrial England: A Future Perfect View of Oxford's Motopolis. Archaeologies 6 (1):167-180

Perosino MC. 2012. Hacia una reconstrucción de las identidades desaparecidas. In Historias Desaparecidas. Arqueología, memoria y violencia política, ed. A Zarankin, MA Salerno, MC Perosino, pp. 35-44. Córdoba: Encuentro Grupo Editor/Facultad de Humanidades, Universidad Nacional de Catamarca

Pétursdóttir P. 2012. Small things forgotten now included, or what else do things deserve?. International Journal of historical archaeology, 16(3): 577-603

Pétursdóttir P. 2013. Concrete matters: Ruins of modernity and the things called heritage. Journal of Social Archaeology 13(1): 31-53

Pétursdóttir P, Olsen B. 2014a. Imaging modern decay. Journal of Contemporary Archaeology, 1(1):7-23

Pétursdóttir P, Olsen B. 2014b. An archaeology of ruins. In Ruin Memories: Materialities, Aesthetics and the Archaeology of the Recent Past, ed. B Olsen, P Pétursdóttir, pp. 3-30. Abingdon/New York: Routledge

Piccini A. 2015. Media-Archaeologies: An Invitation. Journal of Contemporary Archaeology 2(1):1-8

Piccini A, Holtorf C. 2009. Introduction: Fragments from a Conversation about Contemporary Archaeologies. In Contemporary archaeologies. Excavating Now, ed. C Holtorf, A Piccini, pp. 9-30. Bern: Peter Lang 
Powers N, Sibun L. 2013. Forensic Archaeology. In The Oxford Handbook of the Archaeology of the Contemporary World, ed. P Graves-Brown, R Harrison, A Piccini, pp. 40-53. Oxford/New York Oxford University Press

Prieto, M, Vila, XMA. 2014. "Although The Loneliness is Great, Greater Yet is the Love of my Country”. Journal of Contemporary Archaeology 1:323-350

Rabinow P. 2008. Marking Time: On the Anthropology of the Contemporary. Princeton/Oxford: Princeton University Press

Rabinow P. 2011. The Accompaniment: Assembling the Contemporary. Chicago/London: University of Chicago Press

Rabinow P, Marcus GE, Faubion J, Rees, T. 2008. Designs for an Anthropology of the Contemporary., Durham, NC:. Duke University Press

Rathje WL. 1978. Archaeological Ethnography...Because sometimes it is better to give than to receive. In Explorations in Ethnoarchaeology, ed. R Gould, pp. 49-76. Albuquerque, NM: University of New Mexico Press

Rathje WL. 1979. Modern Material Culture Studies. Advances in Archaeological Method and Theory 2:1-37

Rathje WL. 1991. Once and future landfills. National Geographic 179(5):116-34

Rathje WL. 2001. Integrated Archaeology: A Garbage Paradigm. In Archaeologies of the Contemporary Past, ed. V Buchli, G Lucas, pp. 63-76. London/New York: Routledge

Rathje WL, Murphy C. 1992 Rubbish! The Archaeology of Garbage. New York: HarperCollins Publishers

Redman CL, ed. 1973. Research and Theory in Current Archeology. New York: John Wiley and Sons

Reno J. 2013. Waste. In The Oxford Handbook of the Archaeology of the Contemporary World, ed. P Graves-Brown, R Harrison, A Piccini, pp. 261-272. Oxford/New York: Oxford University Press

Renshaw L 2011. Exhuming Loss: Memory, Materiality and Mass Graves of the Spanish Civil War. Walnut Creek, CA: Left Coast Press Inc

Rodríguez Suárez R. 2009. The Archaeology of a Search: An Archaeological Search; The History of the Finding of "Che" Guevara's Remains. In Memories from Darkness: Archaeology of Repression and Resistance in Latin America, ed. PPA Funari, A Zarankin, MA Salerno, pp. 129144. New York/London: Springer

Ryzewski K. 2015. No home for the "ordinary gamut': A historical archaeology of community displacement and the creation of Detroit, City Beautiful. Journal of Social Archaeology 15(3):408431

Salerno MA. 2009. "They Must Have Done Something Wrong...": The Construction of "Subversion" as a Social Category and the Reshaping of Identities Through Body and Dress 
(Argentina, 1976-1983). In Memories from Darkness: Archaeology of Repression and Resistance in Latin America, ed. PPA Funari, A Zarankin, MA Salerno, pp. 81-104. New York/London: Springer

Salwen BL. 1973. Archeology in Megalopolis. In Research and Theory in Current Archeology, ed. CL Redman, pp. 151-163. New York: John Wiley and Sons

San Francisco A, Fuentes M, Sepúlveda J. 2012. Hacía una arqueología del estadio Víctor Jara: Campo de detención y tortura masiva de la dictadura en Chile (1973-1974). Revista de Arqueología Histórica Argentina y Latinoamericana 4: 91-116

Schiffer MB. 1991. The Portable Radio in American Life. Tucson, AZ: University of Arizona Press

Schiffer MB. 2000. Indigenous theories, scientific theories and product histories. In Matter, Materiality and Modern Culture, ed. P Graves-Brown, pp. 172-196. London/New York: Routledge

Schofield J. 2009. The Archaeology of Office Cultures and Corporate Memory. Archaeologies 5(2):293-305

Schofield J, ed. 2009. Defining Moments: Dramatic Archaeologies of the Twentieth-Century. Oxford, UK: Archaeopress

Schofield J, Anderton M. 2000. The Queer Archaeology of Green Gate: Interpreting Contested Space at Greenham Common Airbase. World Archaeology 32(2):236-251

Schofield J, Morrissey E. 2013. Strait Street: Malta's Red-Light District Revealed. San Venera, Malta: Midsea Books

Schuyler RL. 1978. The Spoken Word, the Written Word, Observed Behavior, and Preserved Behavior: The Contexts Available to the Archaeologist. In Historical Archaeology: A Guide to Substantive and Theoretical Contributions, ed. RL Schuyler, pp. 267-277. Farmingdale, NY: Baywood Press

Shanks M. 2012. The Archaeological Imagination. Walnut Creek, CA: Left Coast Press

Shanks M, Tilley C. 1992 (1987). Re-constructing Archaeology (2nd edn). Cambridge/New York: Cambridge University Press

Shanks M, Platt D, Rathje WL. 2004. The perfume of garbage: modernity and the archaeological. Modernism/modernity 11(1):61-83

Silliman SW. 2004. Lost Laborers in Colonial California: Native Americans and the Archaeology of Rancho Petaluma. Tucson, AZ: University of Arizona Press

Singleton TA. 1999. "I, Too, Am America”: Archaeological Studies of African-American Life. Charlottesville, VA: University Press of Virginia

Snow CC, Levine L, Lukash L, Tedeschi LG, Orrego C, Stover E. 1984. The investigation of the human remains of the disappeared in Argentina. American Journal of Forensic Medicine and Pathology 5:297-299

Steele C. 2008. Archaeology and the forensic investigation of recent mass graves: Ethical issues for a new practice of archaeology. Archaeologies 4(3):414-428. 
Stratton M, Trinder, B. 2000. Twentieth Century Industrial Archaeology. London/New York: Routledge

Taffel S. 2015. Archaeologies of electronic waste. Journal of Contemporary Archaeology 2(1):7885

Tarlow S. 2007. The Archaeology of Improvement in Britain, 1750- 1850. Cambridge, UK:

Cambridge University Press

Thomas J. 2004. Archaeology and modernity. London, UK: Psychology Press

Thomas J. 2009. Sigmund Freud's archaeological metaphor and archaeology's self-understanding. In Contemporary archaeologies. Excavating Now, ed. C Holtorf, A Piccini, pp. 33-45. Bern: Peter Lang

Torrence R, Clarke A. 2016. Excavating ethnographic collections: negotiations and cross-cultural exchange in Papua New Guinea. World Archaeology 48(2):181-195

Ulin J. 2009. In the Space of the Past: A Family Archaeology. In Contemporary Archaeologies: Excavating Now, ed. C Holtorf, A Piccini, pp. 145-159. Bern: Peter Lang

Voss BL. 2008. The Archaeology of Ethnogenesis: Race and Sexuality in Colonial San Francisco. Berkeley, CA: University of California Press

Voss BL. 2010. Matter Out of Time: The Paradox of the "Contemporary Past". Archaeologies 6(1):181-192

White, CL. 2013. The Burning Man Festival and the Archaeology of Ephemeral and Temporary Gatherings. In The Oxford Handbook of the Archaeology of the Contemporary World, ed. P GravesBrown, R Harrison, A Piccini, pp. 595-609. Oxford/New York: Oxford University Press

Wickstead H, Barber M. 2015. Concrete prehistories: the making of megalithic modernism. Journal of Contemporary Archaeology 2(1):195-216

Wilkie L. 2006. Documentary Archaeology. In The Cambridge Companion to Historical Archaeology, ed. D Hicks, MC Beaudry, pp. 13-33. Cambridge, UK: Cambridge University Press

Wilkie L. 2010. The Lost Boys of Zeta Psi: A Historical Archaeology of Masculinity in a University Fraternity. Berkeley, CA: University of California Press, Berkeley

Witmore C. 2006. Vision, media, noise and the percolation of time: symmetrical approaches to the mediation of the material world. Journal of Material Culture 11(3):267-92

Witmore C. 2013. Which Archaeology? A Question of Chronopolitics. In Reclaiming Archaeology: Beyond the Tropes of Modernity, ed. A González-Ruibal, pp. 130-144. London, UK: Routledge

Wurst LA, Mrozowski SA, eds. 2014. Special Issue: Studying History Backward: Toward an Archaeology of the Future. International Journal of Historical Archaeology 18(2):205-373

Yarrow T. 2003. Artefactual Persons: the Relational Capacities of Persons and Things in the Practice of Excavation. Norwegian Archaeological Review 36(1):65-73 
Zarankin A, Funari, PPA. 2008. "Eternal Sunshine of the Spotless Mind": Archaeology and Construction of Memory of Military Repression in South America (1960-1980). Archaeologies $4(2): 310-327$

Zarankin A, Niro C. 2009. The Materialization of Sadism; Archaeology of Architecture in Clandestine Detention Centers (Argentinean Military Dictatorship, 1976-1983). In Memories from Darkness: Archaeology of Repression and Resistance in Latin America, ed. PPA Funari, A Zarankin, MA Salerno, pp 57-77. New York/London: Springer

Zarankin A, Salerno MA. 2008. Después de la tormenta. Arqueología de la represión en América Latina. Complutum 19(2):21-32

Zarankin A, Salerno MA, Perosino MC, eds. 2012. Historias Desaparecidas. Arqueología, memoria y violencia política. Córdoba: Encuentro Grupo Editor/Facultad de Humanidades, Universidad Nacional de Catamarca

Zimmerman LJ. 2013. Homelessness. In The Oxford Handbook of the Archaeology of the Contemporary World, ed. P Graves-Brown, R Harrison, A Piccini, pp. 336-350. Oxford/New York: Oxford University Press

Zimmerman LJ, Welch J. 2011. Displaced and Barely Visible: Archaeology and the Material Culture of Homelessness. Historical Archaeology 45(10):67-85

Zimmerman LJ, Singleton C, Welch J. 2010. Activism and creating a Translational Archaeology of Homelessness. World Archaeology 42(3):443-54

\section{Related Resources}

Journal of Contemporary Archaeology www.equinoxpub.com/jca

The Argentine Forensic Anthropology Team (Equipo Argentino de Antropología Forense, EAAF) http://www.eaaf.org 